\title{
Motyw niewoli tatarsko-tureckiej w poezji początku XVII wieku. Z perspektywy grzechu
}

Renata Ryba 


\section{Renata Ryba}

\section{Motyw niewoli tatarsko-tureckiej w poezji początku XVII wieku. Z perspektywy grzechu ${ }^{1}$}

$\mathrm{W}$

wydanym w latach dziewięćdziesiątych szesnastego wieku w Rzymie opisie świata: Relazioni universali autor dzich, (iovanni Botero, kreśląc obraz ziem polskich, zamicscił następującą charakterystykę ,prowincji podolskiej”:

równa i wielce żyzna, albowiem tam we dwie lecie dosyć raz siać na polach, bo z ustatków pierwszego roku rodzi się zboże i na drugi rok; ma dosyć soli, którą biorą w jednym jezierze; tanze koni i domowych, i dzikich; więc też i miodów, i wosku, i wołów, i wszelkich dostatków ku żywności.

Jednak w dalszym toku wywodu pojawia się znamienna obserwacja, która rzıca cień na tę wizję krainy „mlekiem i miodem plynącej”:

Lecz, iż ta prowincja jest otwarta, podległa barzo szkodom Tatarów przekopskich, którzy jak szarańcza wpadają niewiadonie do tych tan ludzi i wyprowadzają ınajętności ich i sanych.

Co więcej, informacje odautorskie lapidarnie, lecz dramatycznie dopetnił thumacz tego poczytnego w Polsce dziela, Paweł Eęczycki:

nie wiedzą nçdzni Polacy, jako temu zlemu zabicżeć?

\footnotetext{
' Nin iejszy szkic jest fragmentem przygotow ywanej wiçkszej calości, dotycząccj motywu1 nicwoli tatarsko-tureckiej w literaturze wicku siedemnastego.

' Informacje o Relazioni unincrsali, publikowanych od 1591 roku, ich autorze i polskim thumaczeniu dzicla za-

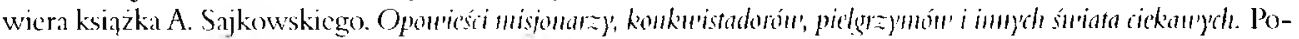
znań 1991, s. 7()-80). Badacz zestawil tu także róznice miçdzy wloskim oryginalem a przekladem, keóry ukazal
} 
Jak widać, włoski geograf uznał pustoszenie Podola i uprowadzanie ludności w niewolę za charakterystyczną i istotną poznawczo „właściwość” opisywanej ziemi. Translator zaś dodatkowo zwrócił uwage na trudny i bolesny, z punktu widzenia obywatcla Rzeczypospolitej, problem obrony - nie tylko przecież Podola, bo dużo większego, południowo-wschodniego, terytorium państwa i jego mieszkańców przed lupieskimi napadami Tatarów. Istotnie, najazdy te - swoiście nieuchronne, bo dokonywane nawet kilka razy do roku, a jednocześnie niespodziewane, bo niezwiązane ze stanem wojny, nierzadko o dużym zasięgu - byly dla Rzeczypospolitej wielce uciązliwe.

Ustalenia historyków dają wiedzç o częstotliwości tatarskich napadów: w pierwszym ćwierćwieczu siedemmastego stulecia, a więc w okresie nas interesującym, bylo ich aż około pięćdziesiąt ${ }^{3}$. Nie dziwi zatem fakt, że tak ważny problem polityczny, spoleczny, a także gospodarczy stal się wyrazistym tematem literackim, znajdującyın realizację, obok wypowiedzi prozatorskich, w rozmaitych formach poetyckich — od drobnych wierszy okolicznościowych: pobudek, lamentacji, wierszowanych nowin, po dzieła o ambicjach epickich, stojących pod znakiem polsko-turecko-tatarskiej batalistyki (na przykład Marcina Paszkowskiego Bi-

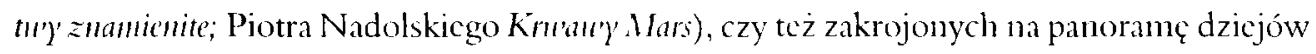
(Wawrzyńca Chlebowskiego Chronologia cesarzón unreckich) bądź wszechstronny opis wspólczesnego państwa Otomanów (M. Paszkowskiego Dzicje tureckic) ${ }^{+}$.

Daje się spostrzec, iż w wielu utworach omawianenu konfliktowi nadawano wykladnię religijną. Juz karty tytulowe nie pozostawialy wątpliwości, że na kresach Rzeczypospolitej toczy się bój ,z nięprzyjaciółmi Krzyża Świçtego" (M. Paszkowski; Bitu'y'znamiènite, Positek Bel$l o n y)$, czemu towarzyszyło nawolywanic do . podniesicnia wojny świçtej” (Józef Wereszczyński, Pobudka) w obronie chrześcijaństwa, a takze, co ważne z punktu widzenia sarmackiej aksjologii, w obronie wolności jako idei (M. Paszkowski, Podole utrapione $)^{5}$. Jak objaśnia Stanislaw Witkowski w Pobudce ludzi querskid — ..Bo wojna ta o krzywdę idzie Przedwiecznego” (k. E);

siç w Polsce trzykrotnic w latach: 16016.1613 i $16.5 \%$. W ninicjszym szkicu. inaczcj niż w rozważaniach A. Sajkowskicgo, cytaty pochodzą z ostatnicgo z wymicnionych wydań. o zmicnionym tytulc: Thearmm sumata u'szysthicigo, cz. 1. Krakón 1659. s. $1+6$.

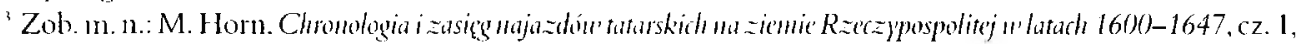
"Studia i Matcrialy do Ilistorii Wojskowości” t. 8, 1962. s. 3-71; D. Skorupa, Stostmki poisko-fatarskic 1.59.5-162.3, Warszawa 2004, s. 233.

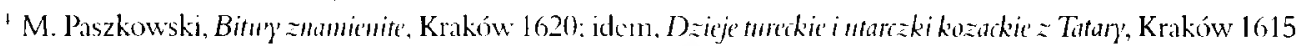
(D-ieje tureckice. przywolywane tu sporadycznic ma prawach jednego z. wielu przykladów to dzicło szczególuc. jeśli chodzi o ujęcie tematu nicwoli. Stanowi bowicm swoista "cncyklopediç" wiedzy o tym zjawisku - pisałam juz o tym obszernicj w innym micjscu: ..Barok. I Listoria - Litcratura - Sztuka“" VIII. 2001. s. 48-53):

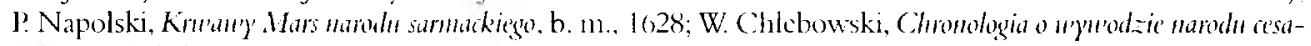
rzour tureckich. b. m.. 1619.

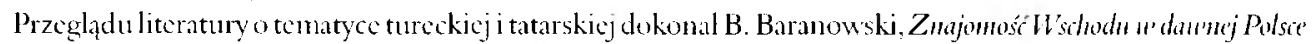

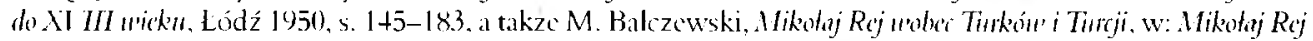

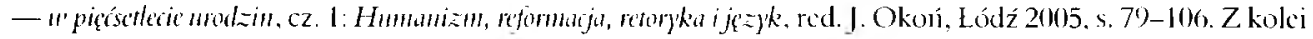
poctyckie turcyki z początku siedemnastego stukecia onowil J. Nowak-Dluzewski, Okolicznościoura prezju polityczma ir Polsci. Z Z ginmm III. Warszawa 1971. s. 233-310.

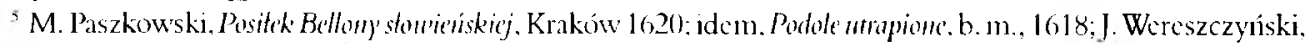

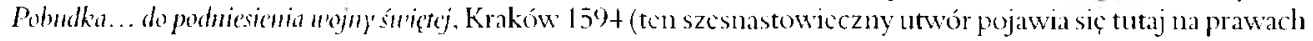


w dodatku wojna z państwem tureckim, w myśl ówczesnych przekonań, państwem despotycznym - gnębicielem wolności: .tyranem chciwyın krwi” (k. D + \%)".

Zaostrzające się u schylku szesnastego i na początku stulecia następnego stosunki polsko-tureckie i polsko-tatarskie spowodowały znaczny wzrost popularności literatury o tematyce tureckjej. W roku 1590 przedrukowano, przypomnijmy, obie turcyki Stanisława Orzechowskiego. W tym samym roku wydano tez ich przekład na język polski ${ }^{7}$. Z kolei w utworach poetyckich odzyly dawne motywy antytureckie, które, rzecz jasna, ulegly modenizacji, przede wszystkim jednak - intensyfikacjì.

Zwracano uwagę, że to nie tatarski sposób na życie („Tatarzy, których lupem się żywić jest obyczaj stary" - jak pisal Krzysztof Okuń w (huratach Z jommuta Augusta') lub czysto polityczne dzialania Wysokiej Porty leżały u podstaw konfliktu, toczącego się na kresach wschodnich. Jak podkreślano, jego istotę stanowila strukturalna nicnawiść wyznawców Proroka do chrześcijan. Whaśnic na ową nienawiść i wynikającą stąd chęć podporządkowania, a raczej zniewolenia całego chrześcijaństwa, wskazuje dobitnie między innymi Wawrzyniec Chlebowski w Chronologii cesarzón tureckich jako na czynuik notywujący zaczepne działania „pogan” wobec Rzeczypospolitej, ciagle wolnej wśród innych, podległych potędze sultańskiej, państw chrześcijańskich:

Gatga Murza [... | |przystąpil]

Za rozkazaniem pewnie cara tureckiego,

Który pragnie panem być chrześcijaństwa wszego.

Tylko z pótnocnych krajów Polatiów się boi,

O tych panstwa zniszczenie zly poganin stoi $\left(\mathrm{k} .(; 2)^{11 "}\right.$.

Celem Turków, w innym micjscu zauwaza ten sam poeta, są nie tylko podboje terytorialne i „zniewolenie fizyczne”, takze te religijne i — „zniewolenie duchowe”:

wyjątku dla cgzcmplifikacji charakterystyezncgo dla tantycl czasów sformulowania, wycksponowancgo przez opata siecicchowskicgo juz na karcic tytulowcj).

"S. Witkuwski, Pohudka hudzi ryerskidh. Zanussé 1621.

Thunaczem byl Jan Januszowski, a polski tytul brzmial: Oksza na Turka, Kraków 159().

*O atmosferze dziesięcioleci przctonu wicków sze smastego i siedemnastego i wynikających stąd tendencjach literackich zob. J. Nowak-Dluzewski. op. cit.. 5.232 i mast.: M. Balczcwski. op. cit.. s. 1(12-106.

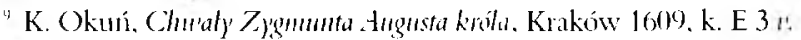

10. Slowa o strachu Turków przed Polakami zawicraja aluzję do popularnego wówczas proroctwa, jakoby whaśnic naród z pólnocy mial pokonać otumaniską potęg̣. Obok motywu _starcj prakty ki tureckicj” litcratura odwolywala się także do wiedzy powszechnej na temat testanentu Sulejunana, w którym cesarz. znając tréśc dawncj wróżby, zabronil wszczynać kontliktów z Polakinni. czego jednak jego nastẹpcy spehnić nic chcicli (M. Paszkowski, Mincrwa = Ligi Chrzśrijaniskicy zehrama. Kraków 1609. k. B-C: W. Chlebowski. Chromologia. k. E 3:

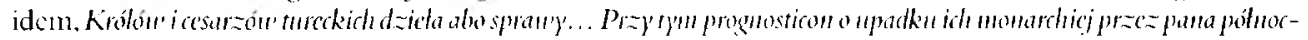
nego, Kraków 1612). Przypommicniu owcj turcekicj wiesze zby i testamentu Sulcjmana Wspanialego czçsto towarzyszyły apcle poctów o unworzenic chrzéścijańskicj lig̣i antytureckicj (zob. utwory Chlebowskicgo i Paszkowskicg(o). 
Nie dosyć na tym mają: zniewolić w nas ciała, Alc chcą, by pamiątka wiary nic zostala (k. D 2).

Jak wiadomo, myślenie o walce z Turkami i Tatarami w kategoriach wielkiego starcia chrystianizmu $z$ islamem było w mentalności staropolskiej powszechne. Jednak permanentny napór żywiołu turecko-tatarskiego na ziemic Rzeczypospolitej, dotkliwe szkody materialne, cierpienic nieszkańców poludniowo-wschodnich województw, wreszcie miejsze lub większe porazki militarne, z bitwą cecorską w 1620 roku jako punktem kulminacyjnym niepowodzeń - wymagaly dodatkowych wyjaśnień. Pozostając w kręgu cksplikacji religijnych, siçgnięto po mającą źródła biblijne koncepcję pogan jako bicza Bożego. I tym razem na gruncic piśmiennictwa polskiego nie była to myśl nowa. Podjąl ją choćby sam Andrzej Frycz Modrzewski, budıjąc swoistą „definicję” Turka:

Turek jest ten, przez którego Bóg karze i karać będzic grzechy ludu swego ${ }^{11}$.

Koncepcja ta okazała się wielce pomocna, by zrozumieć i oswoić burzliwe wydarzenia, jak te z początku wieku siedemnastego.

Wykorzystali ją poeci. Kasper Twardowski zatytułowal swój utwór wlaśnie Bicz Boży.czyniąc najazdy tatarskie jedną z dotkliwych plag; w dedykacji do Dziejón tureckich Marcin Paszkowski wyrazil przckonanic, ,że to z wolej Pańskicj” fortuna stoi po stronic pogan, przy pomocy których Bóg „bicz kręci”; także Stanisław Witkowski w Przestrodze koronncj wskazal na specyficzne "sfunkcjonalizowanie” wyznawców islanu - "Mahomet - bicz Boży”; wreszcic, chcąc usprawiedliwić klęskę cecorską, Piotr Napolski w Kru'aw'ym Marsie najpierw zalıważa:

bisurmaniec sprośny z przejźrzenia Bożego

Nieraz zapędy czyniąc na włości podolskie,

Ukrainę, Pokucie, cne narody polskie,

Mieczem, ogniem plądrowat $[\ldots]$,

następpnie dopowiada:

${ }^{1} \mathrm{Na}$ ten fragment dzicla Modrzewskiego De repullicu enendunda zwrócil uwagę B. Baranowski. op. cit., s. 43. Podboje państw clarześcijańskich przcz Turków takzo uznal za karç Boga Bartonicej (icorgiewicz, autor poczytnych od polowy szesnastego wicku w Europic dzicł. doryczących państwa sultanów, m.in. takich jak De

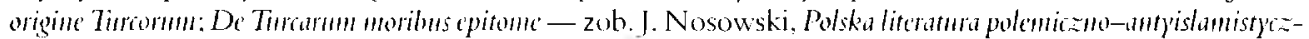
maXI T. XI II i XI III w., t. 1. Warszawa 1974. s. 61. I)zicła Gcorgicwicza odcisnçly tez piętno na polskicj literaturze o tematyce tureckicj: związki z piśnicnnictwem tego autora wykazuja m.in. utwory Chlcbowskiego i Paszkowskicgo, co będzic przedmiotem moich odreçbnych obscrwacji. Dodajmy jeszcze. iż z powodu biblijncgo pochodzenia - koncepcja: pogganic jako narzẹdzic w rçku Boga znajdowała zastosowanic w odnicsicnin do rozmlaitych sytuacji dzicjowych — między innymi papicz Grzcgorz I Wiclki taką wlaśnic ,instrumentalna" funkcjç przypisal Longobardom, za pomocą których Stwórca chcial ukarać pogrązoną w grzechu

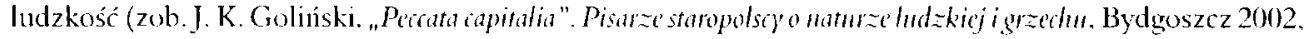
5. 35$)$. 
[...] z wolcj Wszechmocnego

Wziął bicz sprośny polianiec $(\mathrm{k} . \mathrm{B}+\mathrm{u})^{12}$.

Nawet Wojciech Kicki w Dialogu o obronic Ukrainy, raczej stroniący wanalizic przyczyn najazdów tatarskich od bezpośrednich ujẹc w kategoriach grzechu, w Przedmoure do taskan'ego czytelnika wysuwa przypuszczenic, że w owych napadach należy upatrywá́ "wielkie jakieś skaranie Boze" (k. A 2 r.) . $^{13}$.

Myślenie o ekspansji tatarsko-tureckiej w kitegoriach bicza Bożego miało znaczący walor konsolacyjny. Przede wszystkim - to nie najeźdźcy, ale sam Bóg zadaje Polakom razy. "Nie Scyta skrócil mocy zołnierstwu mężnemu" (k. B 4 u.) - pociesza przywołany przed chwila Napolski, opisując przegraną bitwę pod Cecorą. Cojednak w tej koncepcji najważniejsze owe „ciosy” są wyrazem miłości Boga, bo spadają na naród wybrany. To „wybrany lud” Bóg „poleruje”, poshugując się tatarskimi hordami, jak objaśnia wypadki roku 1618 Piotr Gorczyn

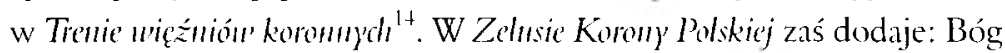

$$
\begin{aligned}
& {[\ldots] \text { z swej świętej milości }} \\
& \text { Przestrzega plaga }[\ldots](\text { k. B 2 })^{15}-
\end{aligned}
$$

znów w postaci Tatarzyna.

Daje się zauważyć, ze w omawianych utworach, zdominowanych przez religijną wykladnię zdarzeń, dochodzą do glosu nie tylko, co oczywiste, wątki antytureckie. Tego typu „turcyki" są utrzymane w znacznych partiach tekstu w poctyce rozrachunku, przybicrają tonacjç nagany i napominania Polaków, bo wlaśnic dziçki temu można bylo dopełnić wizję narodu wybranego o aspekt nadziei na odmianç losu. Plagi przemina, pod warunkicm że zbiorowośç uświadomi sobic blędy i poprawi postẹpowanıie:

A Bóg na niebie, widząc nasze zlości,

Czeka poprawy |...| (Gorczyn, Zilus, k. B 2).

Naród polski nie jest więc, w myśl powyższych przekonań, ofiarą niewinna, gdyż „zabrnąl w grzechy" (Gorczyn, Tren uręzniou, k. B). Dhatego też w wielu utworach pojawiają się swoiste katalogi win narodowych. Odnajdujemy je w tekstach Gorczyna (Zelus Korony Polskiej; Tren unizzunou'); w pobudkach Witkowskiego (Pracsroga koromma: Pobudka ludzi rycerskich); takzc w Biczu Bo ży" Twardowskiego, gdzic personifikowanc grzechy, na wzór moralitetowy, zajęly

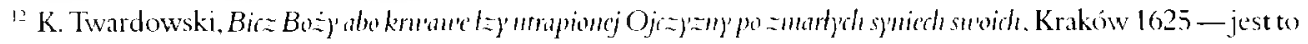

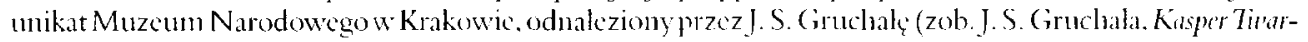

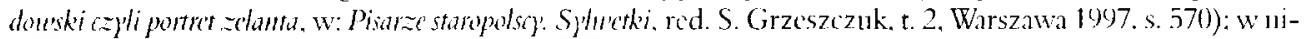
nicjszym szkicu cytaty pochodzą z drugicj edycji utworn Fwardowskicgo, dokonancj przcz Piotra P.rteszcza

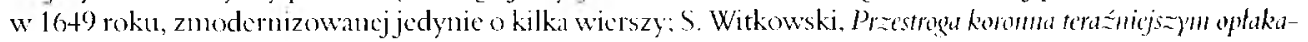
n)'m cassom i potommym stu亡qca. Kraków 1613.

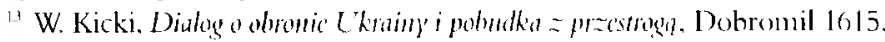

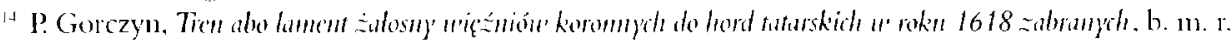

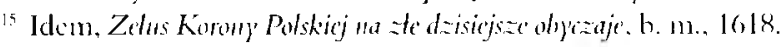


pozycje wojskowe, strategiczne (Chciwość „obozem stançła”, Zdrada , namioty rozpięła”), otaczając lamentują̧a Ojczyznę (k. A 4). Napolski z kolei polożyl nacisk na grzechy społeczne, wytykając szlachcie wszelkie nieprawości wobec poddanych (k, B $4 v-\mathrm{C})$. W tym miejscu, według poety, zaczyna się rola pogan, którzy „nam [szlachcie] z wolej Bożej wet za wet oddają" (k. B 4 l:).

Twórcy, podejmując tematykę konfliktów polsko-tatarsko-tureckich z perspektywy religijnej, nie poprzestawali na refleksjach natury ogólnej. Ich utwory pełne są konkretów wstrząsających opisów, ilustrujących, w jaki sposób koncepcja bicza Bożego realizowala się w rzeczywistości. Pojawiają się zatem obrazy kraju spustoszonego przez niszczycielską silę, tożsamą z jedną z plag egipskich — „szarańczą ze Wschodı” (Chlcbowski, Chronologia, k. F 3).

Destrukcyjną moc najazdów tatarskich uwydatnial wykorzystywany przez twórców kontrast między z jednej strony obrazem bujności natury ukraińskiej i podolskiej, bogactwem wypracowanym przez mieszkańców tych krain, a przerażająca wizją zniszczeń, dokonywanych przez Tatarów. Metaforycznym uogólıieniem poslıżył się Wojciech Rakowski w Pobudce:

Często pohańcy zlote kraje płuczą $\lfloor\ldots\rfloor$

Popiolem wlości wszystkie przyrzucając (k. B 3) $)^{(t)}$.

Natomiast technikę detalu zastosowat Chlebowski w Chronologii cesarzón:

Wsi, miasteczka kosztowne pozarem zniesione,

$[\ldots]$ dwory pyszune z gruntu wywrócone (k. F 2 r) ;

[...] spalił [poganin] inszych miast przedmieścia:

Kędy przedtym towary napchniały rynki,

Mahmazyje, alakant, pieprze i rozynki:

Gdzie podolańskie konie i thuste czabany

Stawaly w jego rynku $|\ldots|$ (k. F 3).

Zniszczenia pod piórem poetów nabierają wymiaru totalnego i monstrualnego: mało, ze ziemia „stęka od ciężkich razów”, więcej - także .Prut [...] Czerwieni się [...] krwią" (Chlebowski, Chronologia, k. F 3). Kraj ogarnia "pogańska apokalipsa”:

Nie masz żadnego kįta, kędyby pogańskie

Kopyto nic zapadlo na nwy chrzéściańskie.

Wszerz, wzdłuż, w okrąg i poprzek psy swe zapuścili,

Zamki, miasta, folwarki wniwecz spustoszyli (Twardowski, Bicz Boży, k. B3).

${ }^{16}$ W. Rakowski. Pobudka zacnjm sjmom Kormy Polskicj. Kraków 1620). 
Wizję zniszczonego kraju w sposób zasadniczy wspóltworzy poetycka refleksja nad zjawiskiem niewoli ${ }^{17}$. Niejednokrotnie postrzegano je jako przynależne do repertuaru kar $130-$ skich. Interpretacja rzeczywistości, niosącej zagrożenie dla calych narodów chrześcijańskich i jednostek, przez pryzmat grzechu i kary niewoli znajdowała przecicź potwierdzenie w Biblii: Bóg od czasów biblijnych wlaśnie plagą niewoli naznaczal i doświadczal.

W obscrwowanych utworach poeci, opisując plage niewoli z caląjej dotkliwością, ukazywali naród doznający najwyższego cierpienia. Cierpienie rozpoczynało się wraz z chwilą pojmania, kiedy to w sposób okrutny taksowano ludzi wedhug ich ..przydatności”:

[pohaniec] ludźmi brakowat:

Dziatki male rozcinal, a starym zdejmowal

Glowy, którzy nie mogli za nim prędko chodzić (Paszkowski, Bitu'y, k. B 3);

rozdzielano rodziny:

[Mać] Patrzy smutna na dziewkę, a ociec na syna,

A każdy różno w trokach z nich u Tátarzyna (Paszkowski, Bitu'y, k. B 3 u.).

Cierpienie ukazywane jest jako wszechobecne. Dotykalo zarówno tych rodziców, którzy wraz z dziećmi dostali się w ręce poganı, jak i tych, którzy uszli z życiemı i zachowali wolnośc:

Więc jeśli ociec pozostal żyw który,

Zabrano wszystko z namilszyni córy.

Drugi, żalością zdjęty niepojęctą,

Patrzy nal ściętą (Gorczyn, Zelus, k. B).

Wizję rodzinnej tragedii dopehniat godny pożałowania los synów, zabranych w jasyr. Przy czyn z jednej strony chodziło o potonków płci męskicj; z drugiej — o „synów ojczyzny”, cierpiących w pogańskich okowach. Wówczas ojczyzna mogła przybierać postać matki, personifikowanej i lannentującej nad niedolą swych „dzieci”, a także naponinającej pozostalych „synów”, by ci ujęli siç za swymi „braćmi”":

Wejrzycież na mię, o synowie mili!

Dajcie ojczyźnie swej ponroc w tej chwili.

Niech moje ruszy was napominanie

I dziatek moich w okowach stękanie (Paszkowski, Podole utrapionce, k. A 3).

\footnotetext{
${ }^{17}$ Szczególnie sugestywne obrazy wyszly weześnicj spod pión Bartosza Paprockicgo. który w utworze Historia

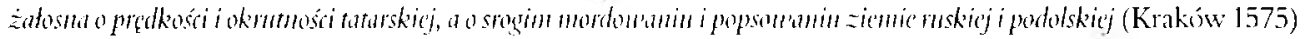

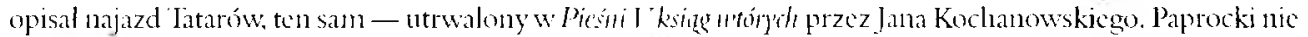
tylko pokazal ogrom zniszczen materialnych. poslug̣jąc siç choćby motywem kapryśnej fortuny, ktoja najpierw niczuykle hojnic obdarowala poludniowo-wschodnic zicnuc. by następnic wszystko odchrać (k. C +r). Poeta w sposób naturalistyczny przedstawial gehennç tamtejszej ludności. z joj waznym skiadnikicm - nicwolą. wymicnając często, zgodnie z stosowana poctyką epatowania szczégólem. nazwiska tych. którzy w dramatycznych okolicznościach stali siç zywą zdobycza wrogów.
} 
Uruchomienie metaforyki rodzinnej niewątpliwie mialo na celı intensyfikację ekspresji wezwań do czynu - w imiç solidarności narodowcj ( „dzieci” jedncj „matki”) i stanowej ( ,ratuj bracia”"; "szlachecka to krew" - Paszkowski, Positek Bellony, k. A 3).

W ogóle dostrzeżenie i ksponowanie w zjawisku niewoli aspektu rodzinnego shużyło budzeniu silnych emocji, uczucia litości, a nawet postawy wspólodczuwania przez odwołanie się do wartości bliskich każdenu. Z kolei sanna kara traci $w$ ten sposób cechy abstrakcji, realizując się w losie pędzonych w jasyr - córki, syna, brata. I wlaśnic odpowiedzialność za ich niedolę spada na grzeszników:

Drugie w dalekie zaprzedane kraje,

Opłakiwając nasze zle zuyczaje (Gorczyn, Zelus, k. A 4 ı).

Odpowiedzialność jest tym większa, że często cierpią niewinni: dzieci, ,panny uczciwe”, "cnotliwe wdowy" (Gorczyn, Tren więúnión, k. A $u$.).

Interesujący jest takze poctycki komentarz do wydarzeń cecorskich w Kru'au'y'm Marsic Napolskiego. Według poety, rycerze biorący udział w bitwie, szczególnie ci, którzy polegli lub dostali się do niewoli - ponieśli of rarę za grzechy „ludu Boga”: to ,zlości” — „niewinnych dla winnych w moc pogańską dały" (k. B 4l.). Zadziałało zatem wyjątkowe prawo wyłączenia z kręgu winy grupy przedstawicicli warstwy szlacheckicj - najbardziej przecież, z racji pozycji i funkcji w państwie, obciążanej przez poetów grzechami wywolującymi plagi. To „wylączenie" było możliwe, dlatego że cecorscy żołnierze przeciwstawili się potędze pogańskiej, nie popehniajac grzechu zaniedbania. Jeszcze dalej w waloryzacji czynu rycerza chrześcijańskicgo posunąt się Witkowski w Pobudec ludzi rycerskid. Znaną myśl: „niebo dla rycerza” poddał najwyższej idealizacji - w mowic do wojska przed bitwa żołnierzom gotowym „o krzywdę Bożą umrzeć” Żólkiewski obiecuje „męczeńską koronę” (k. B 2 u.)

Chąc wydobyć powage i ciçżar „rozleniwienia patriotycznego” jako grzechu wobec narodu wybranego, poeci ważnym składnikiem obrazu niewoli uczynili motyw poniżenia, zresztą znów o wyraźnej inspiracji biblijnej. Zbiorowość swoimi występkami wystawiła się na pośmiewisko pogan, bioracyclı w jasyr jej przedstawicieli:

Wiążą, ścinają bracią, a Turczyn się śmieje,

A my, przez szpary patrząc, w' grzechach się kochamy

(Witkowski, Praestroga, k. 32 '?.).

W dodatku wróg szydzi z Polaków - w poczuciu catkowitej bezkarności:

Często polnaniec, rwąc mię, z was się śmieje,

Widzicie, gdy chce po plon, do was jedzie,

\footnotetext{
${ }^{18}$ Rozwazania na temat rycerskicj śmicrci i wicczncj liagrody zaczyn - zob. E. R. Curtius, Literatura europejska

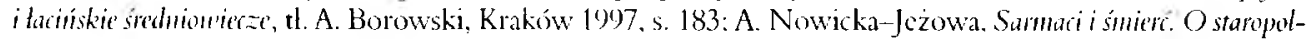
skicj poesii zatolnej. Warszawa 1992. s. 176-179.
} 
A was w czymborze kilka tysiąc wiedzie,

Żadnego niskąd odporu nie mając (Paszkowski, Lkraina, k. B ı."

Ekspresywną wizję poniżenia narodu przedstawił Gorczyn w Zelusic Korony' Polskiej, posługując się przytoczeniem słów rzuconych przez nieprzyjaciól w chwili porywania plouu:

Z których siç [...], gdy ich z domu brano

Tak urągano:

„Nie myśliliście w czas o swej obronie,

Tylko o pompie, a o stroju żonie" $[\ldots]$

Tak siç urąga widząc lud nicdbały,

Tak na swój kolczan każe pełnostrzały.

Gunuśnością nasza poganin brzydliwy

Teraz szczęśliwy (k. B u).

Odınalowana przez poetę scenka zawiera odwrócenie znanego motywu pochwaty: dokonania bohatera lub zbiorowości są tak wielkie, że zostaja dostrzeżone i wyslawione nawet przez wrogów ${ }^{20}$. Wymowa przytoczonego obrazka jest przeciwna - to zaniedbania są tak ogromne, ze przeciwnicy nie tylko je dostrzegaja, ale nawet wykorzystują do pouczenia, godząc tym samyın w dumę narodową.

Motyw poniżenia narodu mógł przybierać różne warianty. Bodaj najbardziej znany, rozpowszechniony przez Jana Kochanowskiego w stynnej Pieśni I 'ksigg wtórych, mówi o zbrukaniu przez pogan przestrzeni intymnej, związanej z rodziną: „Polskie córy pohancom ścielą brzydkic loze" (Gorczyn, Tren więźnión, k. A 2) ${ }^{21}$.

Wysoki stopień ekspresji motyw poniżenia narodu osiąga także w delıumanizującyın porównaniu ludzi branych w niewolę do bydla i traktowaniu ich wylącznie jako towaru przeznaczoncgo do handlu. I tak ludzie „pędzeni” sa ,jak bydto” (Paszkowski, Podole, k. A 2 »), „równo z bydlem” (Napolski, Kn'au'y Mars, k. C 2 r), porywani „w niewolę // Z bydlem, z dobytkiem" (Paszkowski, Ukraina, k. B !), a także - w jeszcze innej "spiętrzonej” poetycko odmianie -

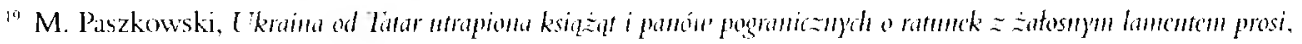
Kraków 1618.

211 Realizacja tego motywu pojawila się w literaturze polskicj bardzo wcześnic, bo w Kronice polskicj Anonima zw. Gallem w picśni wojowników nicmicckich. wyslawiającycls zalety i zashugi Bolesława III (Ks. III. $\operatorname{rozd} z \cdot 1(0)$.

21 O znaczeniu slynncj Pieśni o spustuszenim Porlola jako wzon dla licznych utworów poctyckich o wydźwiçku

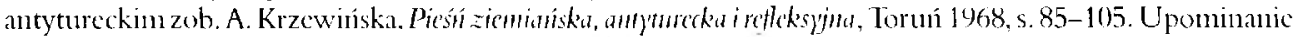
siç o obronę godności kobict podezas wojny nalczato do ntrwalonego zasobu argumentów pobudkowych:

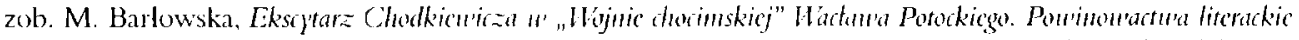

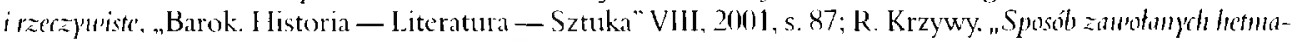

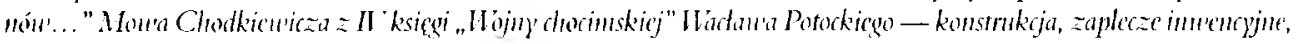
"r')"moura ideoura, .. Roczniki Humanistyczne" t. 49. 2001, z. 1. s. 135. 
$[\ldots]$ pohaniec brzydliwy

Zwiazawszy jak barany na zysk zapalczywy,

[wziął] trzodę żałosną (Gorczyn, Tren, k. A 2 v).

Poniżenic jest tym wiçksze, że jego sprawca to nieprzyjaciel, w porównaniu z narodem polskim stojący nizej w rozwoju cywilizacyjnym: „sąsiad, który dom wozi na kolasie” (Gorczyn, Tren, k. A $u$; podobnie: tegoż, Zelus, k. B $u$.). Deprecjonowanie przeciwnika pehilo wyraziste funkcje pobudkowe, miało poruszać poczucie narodowej godności i motywować do czynu. Obok tego jednak ukazanie tryumfującego wroga jako dzikiego nomady stanowito dodatkowy argument przemawiający za koncepcją gniewu Bozego, który zawisł nad ludem wybranym. Pelne zdumienia slowa: „By wzdy kto, ale przewodzi w tym czasie...”-znajduja wyjaśnienie: „Odjąl Bóg rozum i baczenie wszystko” (Gorczyn, Zelus, k. B ».) - oczywiście po to, by ukarać.

Z jednej strony, motyw poniżenia narodu stal się wyrazem dotkliwości kary niewoli, w sposób wstrząsający ukazywal konsckwencje grzechów calej zbiorowości i ogrom gnicwu Pańskiego. Z drugiej strony zaś za jego pomocą uzyskiwano efekty perswazyjne, między innymi przez zawstydzenie, niekiedy werbalizowane: „sromota nasza, niestety sromota” (Gor(zyn, Zelus, k. B 1').

Daje się zauważyć, że obraz udręk niewoli byl poetycko ksztaltowany na wzór cierpień piekielnych. W pierwszej fazie budowania tego obrazı chętnie odwolywano się do topikj mortualnej. Przede wszystkim wskazywano na masowy charakter niewoli („Tatarzyn [...] Więźniów tysiącami do hordy prowadzi” - Paszkowski, Podole, k. A 3) i na catkowitą równość wobec tego zjawiska. W utworach pojawiajł̨ się pelne dynamizmu wizje ludzi należących do różnych stanów, pędzonych na niewolnicze targi, niczym w makabrycznym korowodzie śmierci ${ }^{22}$.

Mortualne nacechowanie obrazu niewoli uwidacznia się również we wspólnej „wlaściwości” momentów umierania i pojmania: mają one charakter „graniczny”. Pojmanie, tak samo jak zgon, stanowi swoisty moment przejścia, tyle że nie z życia w stan śmierci, a z wolności w niewolę. Odmiana losu też jest gwaltowna i calkuwita:

Pieszczoty i rozkoszy wszystkie odstapily,

Frasunki na ich micjsce trudne przystipiły (Gorczyn, Tren, k. A 2-3

Wskazuje się nieraz na nieodwracalność sytuacji. Niewola, na podobieństwo śmierci, na zawsze rozdziela rodziny:

\footnotetext{
"Co wiçcej. sama postać Tatara podlega często womawianych utworach swoistcmu ,zdialogizowaniu" z barokowymi wyobrazeniann śmicrci. W odniesicniı do Tatarów bowicm stosowane byly określenia, jakich pocci używali, kreśląc wizerunki śmierci. jak choćby: rozbójnik. myśliwy. Przedstawiano ich przez pryzmat destrukcji iagresji. Przypommijny jeszcze za A. Nowicką-fczomą (op. cit., s. 196). ze u schylku wicku sicdemnastego M. I. Kuligowski w Heraklicio dhreśijaniskim, wierszowanej przeróbe dzicha P. Besseusza, wykorzystal postać Tatara w podobnej funkcji. odwracając jednak ., strukturę゙ motywut: to śmieré zostala porównana do Tatara (a nic. jak powyżej, Tatar do śmerci).
} 
Ojciec syna nic ujźrzy, brat rodzony brata,

Nie ucieszy się matka juz z namilszej córy (Gorczyn, Tén, k. A 2).

Brańcy przechodzą z jednego świata - bezpiccznegro, naznaczonego uczuciem milości — w drugi: obcy, budzący lęk, w dodatkı nie z własnej woli:

Pędzą [nieszczęsne córy] w nieznajome strony,

Zostawuja przez dziçki kraj swöj ulubiony,

A na swą się ojczyznę co raz oglądając,

Wzdychają, po niewoli swój dom opuszczając

(Twardowski, Bicz Boj)', k. B 3 ॥.).

Cowięcej, mówi się o niemożności powrotu z ,przestrzeni niewoli” - z ,tamtego świata": nie tylko obcego, także bardzo oddaloncgo. Zazwyczaj to oddalenie bywa określane ogólnie i zarazem enigmatycznie: „dalekie krajc” (Gorczyn, Zchs, k. A 4 i.); czasem - precyzyjniej, co nie znaczy, że mniej tajemniczo i mmiej przerażająco: „astrachańskic góry”, „murzyńska ziemia" (Gorczyn, Tren, k. A 2).

Poeci nie pozostawiają wątpliwości co do istoty zjawiska niewoli. Definiuja go wprost jako „piekielną mçkę" (Chlebowski, Chronologia césaróur, k. F 2); nówią o skrajnym nieszczęściu: "stokroć nieszczęsny, kto wpadnie w to sidto” (Paszkowski, Podole, k. A $2 v$ ) i o triumfie zla w losie czlowieka niewolnego: „Ciemność miasto bialego dnia w oczach nam świeci” (Gorczyn, Tren, k. A 2).

Charakterystyki ogólne znajdują rozwinięcie w szczególowych wyobrażeniach pobytu w niewoli, równiez podleglych infernalizacji.

Przcde wszystkim jeńcy, podobnie jak grzesznicy skazani na pickło, doznają uczucia opuszczenia, zagubienia i braku nadzici na zmianę swej doli ${ }^{2.3}$ :

Serce ondlewa, bo w żadnej rozmowic

Pociechy nie masz, ratunek niespory.

Pan Bóg wysoko [...] (Paszkowski, Positek, k. A 3).

Jednocześnie opisując warunki by towania w nicwoli, poeci sięgają do „pickielnych rekwizytorni”, zwłaszcza wówczas gdy niewola zostaje potraktowana jako miejsce odpłaty za grzechy, a „przedmiot” rozkoszodajny zamienia się na adekwatne narzędzie tortury ${ }^{24}$ : niewolnik

Za manele kajdany, za lańcuch okowy

Nosi, które mu sprawil grzech jego surowy (Gorczyn, Tien, k. A 3).

Zapłatę otrzymują także ci, którzy ciemiężyli poddanych, by spehnić swe kaprysy:

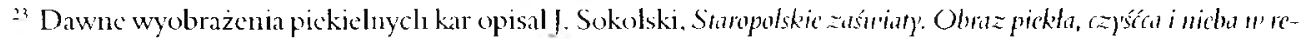

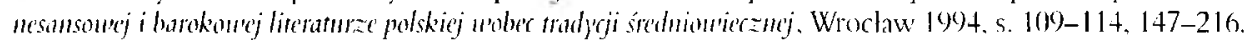

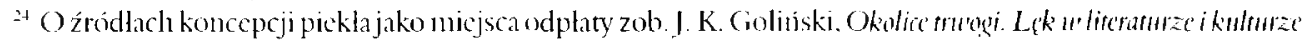
dau'ncj Polski. Bydgoszcz 1997. s. 212-25is.
} 
Dopiero widzi on pan z gospodynia,

$$
\text { Co zbytki czynią. }
$$

Niektórzy za to srogie pęta noszą,

A drudzy clıleba na posilek proszą,

We lzach go moczą dla zbytnicj twardości

W tatarskiej wlości. (Gorczyn, Zelus, k. B 3 r.).

Tak więc winowajcy, zgodnie zresztą ze znanym od antyku wyobrażeniem, doznają najwyższych mąk, bo nadmiar zamienil siç $w$ niedostatek, czému towarzyszy dojmująca niemożność zaspokojenia wszelkich potrzeb.

Udziałem jeńców stają się najbardzicj dotkliwe męki cielesne: cierpią glód i pragnienie, doświadczają wstydu nagości, ulgi po trudach dnia nic przynosi nawet noc:

Eoże nasze usłane - zelazo okrutne $[\ldots]$

Pościcl - kamienic twarde, odzienie wiatrowe,

Sen - narzekanie, a lzy - poduszki surowe (Gorczyn, Tren, k. A 3).

Dotyka ich wyniszczenic fizyczne ${ }^{25}$. Przemianom w wyglądzie, niczym po śmierci, podlegają zwlaszcza kobiety - piękno przeobraża się w brzydotę $e^{20}$ :

Uroda, którąśmy się przed laty cieszyly

Zwiędla [...] i śliczne lice obrócily

W zmarsk frasunki, i wlosy one utrafione

Ustaly; oczy lzami prawie zaslonione (Gorczyn, Ten, k. A 4).

Jak przystało na picklo, są w nim obecni wykonawcy kar: Turcy i Tatarzy, wyposazeni w atrybuty szatańskie, zarówno fizyczne, jak psychiczne, czego kwintesencjajest celne z punktu widzenia nośności semantycznej określenie obu nacji: „pyszne rogi” (Napolski, Kru'an'y Mars, k. A 4). Skojarzenie tradycyjnego elementu diabelskiego wyglądu, rogów, z tureckim pótksiężycem wywolało kolejną, niejako w sposób oczywisty dopehniająca portret, asocjację podstawowej cechy szatańskiej - pychy.

Niewolnicy pozostają we wladaniu „bestii” (Witkowski, Przestroga koronma, k. B 2), „lwa zajuszonego", „okrutnego sępa” (Gorczyn, Tren, k. A 3) czy wprost - już bez infernalnych teriomorfizmów - poganina „równego szatanowi” (Gorczyn, Tr’n, k. A2). Cowięcej, poganie,

\footnotetext{
${ }^{25}$ Bodaj najbardzicj wstrząsający obraz wyniszczenia istoty ludzkicj w niewoli. ukazantej co prawda nie z perspektywy tanatologiczncj. a jako konsckwencja upadku ideatów szlaclectwa. ducha rycerskicgo i - juz bezpośrednio - wojny znajdıje się w dzicle Sebastiana l iabiana Klonowica: I ïtoria deonmm. „Nogi otaczają twarde zardzewiale kajdany, w wiçzicnnym brudzic przemija wiçksza część życia, zarosłe bruden cate, pokaleczone powrozami cialo, brzydką won wydają pod pachann ręce. cuchnic nicunnyta skóra, z dlugo rosnących w zanicdbaniu wlosów ścicka plugawy il, roi siç od robactwa. moke mają bezpicczną kryjówkç" (fragmenty dzicla

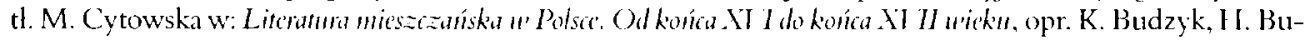
dzykowa, J. Lewański. t. 1, Warszawa 1954, s. 131).

it To oczywiścic jeden z ulubionych motywow barokowych utworów o temaryce wantatywnej - zob. A. Nowicka-Jiżowa. op. cit.. s. $238-2+4$.
} 
znów na podobicństwo sil szatańskich, czerpią radość z grzechów (Gorczyn, Zelus, k. A 4), a cierpienie braíców dodaje im sily:

[... ] swe przeklçte oczy

[karmia] lzami, które z nas pojmanych toczy (Gorczyn, Tren, k. A + ı).

Wreszcie - sa niezmordowani w swych dzialaniach:

Co dzién nowe karania i nowe roboty

Wynyśla nam [bisurmanin]" (ibidcm).

W ogóle miejsce, w którym przyszło znosić więźniom męki, jednoznacznic zostalo określone jako wrogie Bogu _ ..turecki Babilon” (Paszkowski, Bitu'), k. B 4'́), skąd raz po raz, by zawojować świat chrześcijaíski, podnoszą glowy nowi „Gog i Magog” (idem, Podole, k. A3).

Więźniowie, jak pokutujący grzeszuicy, kienuja do Boga modlitwy z prośb̨̨ o ratunek:

Wybaw nas, Panic, przepuść nasze złości,

Wybaw z ciçżkości!

(Chlcbowski, Lament żatosmy', s. 267 $7^{27}$ ).

Skargi wiçźniów są tez kierowane do wspólziomków, a ich bezpośredni charakter wzmaga silę przesłania. Narzekania te bowiem nie są wylącznie „czystą" lamentacją, mającą jedynie wzbudzić wspólczucie. Na podobicństwo eschatologicznych wizji, zawierają przestrogę tym, którzy nadal, pomimo Boskich napominań, ulegają pokusom: „Strzeżcie się, by i was na ten bankict nic porwali" (Gorczyn, Tren, k. A 2 ».). Żale więźniów unaoczniają konsekwencje grzechu, odslaniając przy tym mechanizm waznej zależności: dopóki naród pozostaje w stanie grzechu - dopóty jego przedstawiciele będą cierpié w niewoli tatarsko-tureckiej:

Za wasze zlości bracia pokutuja,

Niewolia czują (Chlebowski, Lant'nt, s.268).

We wstrząsających scenach z niewoli kryje się zatem apel o odnowę moralną̧ narodu. Jednyn z aspektów owej poprawy winien być czyn militarny, podniesiony do rangi wartości duchowej, zmazującej grzech zanicchania obowiązku rycerza chrześcijańskiego. Sam Bóg, jak chcą twórcy omawianych utworów, wzywa do walki za clırześcijan cierpiących w okowach:

[...] Bóg wzywa lud zbrojny,

Byście się mścili ścislych jego wiernych

I sirot w jarzmie pogańskim mizernych (Paszkowski, Podole, k. A 2 1\%).

Tak więc o swoje „dzieci”, zniewolone przez pogan upomina się przede wszystkim Bóg, dalcj - o czym była już mowa - Matka-Ojczyzıa, a nawet przodkowie. do których, za grób, dotarly lamenty brańców:

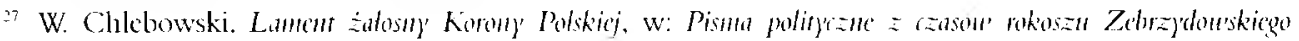
1606-1608, t. 1: Pociaja rokeszan'a, wyd. J. Czubck. Kraków 1916. 
[...] budzą nas krwawe łzy zabranych w nicwolą.

A choć ciała nie manny, przecię serca bolą (Krajewski, Nenia, s. $275^{28}$ ).

Okazuje się bowiem, w tym miejscu jedynie dodajmy, ze wyzwalanie jeńców, zwłaszcza z rąk pogan, należące do etosu rycerza chrześcijańskiego, poezja o tematyce tureckicj uczynila ważnym skladnikiem mitu rycerskich przodków, czego dowodzi między innymi bezpośredni apel, skicrowany do wspólziomków przez Piotra Gorczyna:

Wstąpićby trzeba w swych pradziadów strzemię,

Zgodą uderzyć na pohańską ziemiç.

Niechaj pohaniec swej dumy ukróci.

Bracią nam wróci (Zelus, k. A 4).

Przywoływano postaci dawnych bohaterów kresowych, którzy nie tylko skutecznie odbijali Tatarom „plon”, ale sami brali wrogów do niewoli.

Motyw niewoli, ukazywany przez pryzmat grzechu zaniedbania, wączano także do mitu idealnej przeszłości, kontrontowanej z zepsutą teraźniejszością: dawnicj - „kazdego skrzydly swemi ten Orzel zasłonil”, dziś - „Wiążą, ścinają bracią, a Turczyı się śmieje” (Witkowski, Przestroga, k. B 2 v.).

Za pomocą opisu zjawiska niewoli twórcy interpretowali relację: Bóg — naród wybrany. I tak z jednej strony, pod ich piórem niewola nabierała wymiaru kary w ręku Stwórcy. Z drugiej - pełniła funkcję swoistego sprawdzianu zbiorow'ości wobec doświadczenia tej kary: byla próbą wiary, rycerskości, a także człowieczéństwa.

Rozpatrywanie przez poetów problemu niewoli tatarsko-tureckiej z perspektywy grzechu, kary i pokuty nadawalo mu wyższy sens, pozwalając wpisać ten bolesny element rzeczywistości w ramy boskiego planu „naprawy” narodu wybranego. Zbiorowość, naznaczona piętnem cierpienia, otrzymywala przecież możliwość odpokutowania za występki, a potem nawet jeszcze większego wyniesienia:

Będzieć fortumna ręka Boża z wami,

Gdy nauk jego będziecie strzec sami.

Szczęśliwie granic swych dobędziecie,

Rozumnym męstwem i cudze weźmiecie (Paszkowski, Podole, k. A 3 v).

Jak widać, w poezji o tematyce antytureckiej posługiwano się jeszcze jednym typem argumentu o wykladni religijnej, mającym motywować patriotyczny czyn. Otóż obok obrazu oplakanych konsekwencji grzechu ukazywano wizję "cudownych" efektów poprawy błądzącej zbiorowości. Tym razem bowiem zachętą do dzialania byla perspektywa narodowego triumfu nad „poganami”, odniesionego oczywiście przy pomocy i z woli Boga.

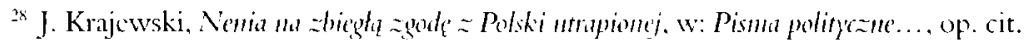

